\title{
Organizational Disruption and Change in Mozambique’s Peace Process
}

Daniel Levine, Graduate Research Fellow

CISSM

School of Public Policy 4113 Van Munching Hall University of Maryland

College Park, MD 20742

Phone: 301-405-7601

Fax: 301-403-8107

E-mail: CISSM@umd.edu
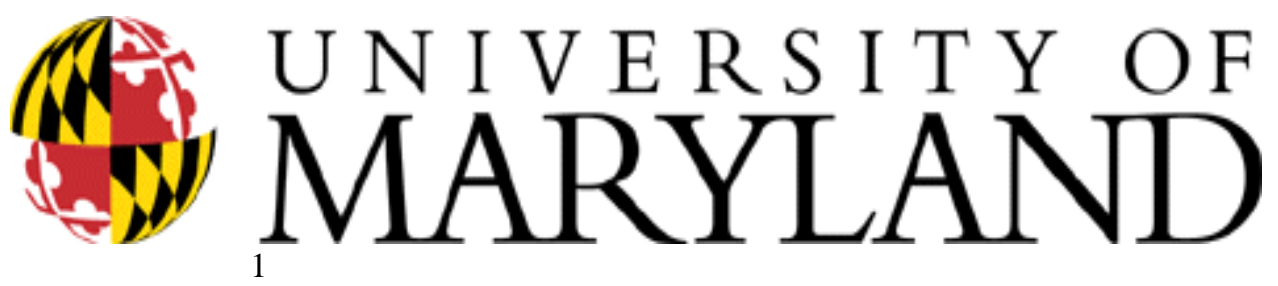


\section{Organizational Disruption and Change in Mozambique’s Peace Process}

Mozambique returned to peace after a brutal civil war, despite imperfect disarmament. Many accounts make some appeal to the 'political will' of the warring factions to shun war and seek peace - such an explanation is not false, but incomplete. Insurgencies' 'will' to fight can be better understood by looking at the organizational structure through which they mobilize violence. In particular, Mozambique's Renamo insurgency was a primarily military organization, making it less resilient to certain kinds of interference. The UN mission failed to disarm Renamo, but did disrupt it by dispersing its combatants geographically. Possibilities for disrupting spoiler organizations, especially through political rather than military tactics, bear further exploration.

In 1994, Mozambique’s Resitência Nacional Moçamicana (Renamo) lost the nation’s first elections. Despite the fact that disarmament during the peace process was deeply imperfect, the insurgents did not violently contest the election results. Much has been written on Mozambique's war and peace, attempting to account for its relatively successful transition. This essay will, I hope, add to that understanding by examining organizational factors that may have contributed to the insurgents' being 'ready' for peace.

The Frente de Liberação de Moçambique (Frelimo) gained control of Mozambique at independence in 1975, and quickly earned the enmity of neighbouring white-ruled Rhodesia by enforcing the UN embargo and giving shelter to Rhodesian guerrilla groups (including Robert Mugabe’s ZANU). In response, the Rhodesian Central Intelligence Organization (CIO), in collaboration with Frelimo dissidents, created Renamo in an effort to destabilize the country. After the collapse of Rhodesia's minority government in 1980, Renamo was transferred 'lock, stock, and barrel' ${ }^{1}$ to South Africa's protection, which supported the movement covertly until 1990. Though Renamo gained some outside support from Western countries that opposed the Marxist Frelimo government, and some Mozambicans were hostile to the government's policies on religion and resettlement, Renamo gained a reputation within and without Mozambique for extreme brutality.

In 1990, peace talks between Frelimo and Renamo began in Rome, under the auspices of the Catholic Society of Sant'Egidio. A General Peace Agreement (GPA) was signed after twelve rounds of talks, in 1992. The UN sent a peacekeeping mission (ONUMOZ) to oversee the withdrawal of foreign forces (mostly Zimbabwean and Malian), disarm the combatants, and oversee elections. ONUMOZ departed soon after the 1994 elections. Since then, though the nation is not without its problems (including poverty and a high crime rate), political violence in Mozambique has been relatively rare and contained. 
Many factors influenced the outcome of the peace process and UN intervention, including the UN mission's strong leadership and a high level of direct UN involvement, a drought that sapped the resources both of the Frelimo government and Renamo insurgents, and the relatively high level of financial and military resources ONUMOZ enjoyed. Most accounts also attribute the success to the 'political will' of one party or another, whether of Renamo leader Afonso Dhlakama (for not contesting the election results, despite disputing them), ${ }^{2}$ the members of the National Election Commission (NEC) and other election workers, ${ }^{3}$ the war-weary population, ${ }^{4}$ or the war-weary parties. ${ }^{5}$ This essay will focus on Renamo’s presumed 'will' to end the war.

'Political will' explanations are not necessarily false, but they are incomplete. The Mozambican people's distaste for the conflict presumably is supposed to entail that the parties to the conflict will be similarly committed to the peace process. But the assumption that the parties draw their strength from mass popular support does not hold for all governments or insurgencies. Conflicts can continue with brutalized populaces and disenchanted soldiers. All movements rely on some relationship with the broader population, but it may not be one that would prevent an insurgency from continuing despite the warweariness of the population, or even of its own soldiers. Even the willingness of the leaders to end the conflict may be insufficient if we cannot safely assume that that the insurgent troops will be more or less fully responsive to their wishes (a point illustrated by the fact that insurgencies often splinter when the leadership signs a peace agreement or ceasefire).

'Political will' explanations benefit from a deeper understanding of the ways in which potential spoilers are organized and can be disrupted - a prominent theme in counterinsurgency literature. While theorists and practitioners of peacekeeping have recognized the similarities between military tactics for dealing with spoilers and counterinsurgency warfare, counterinsurgency theory also has applications to elements of a peacekeeping operation (PKO) of a less violent nature. It is very easy to personify spoiler groups and talk about their goals, desires, incentives, etc. in the aggregate. But 'political will' is a function just as much of internal lines of decision-making, control, and support, as it is of the psychology of individuals involved. These organizational elements are potential points of leverage for a PKO.

Organizational disruption of the Renamo insurgency may have played a role in ONUMOZ' success. The withdrawal of outside support for Renamo following South Africa's political opening began the process or organizational decay, and ONUMOZ helped it along through both the 'pay and scatter' element of its oft-maligned disarmament, demobilization, 
and reintegration (DDR) program and support to Renamo’s organizational restructuring as a political party.

\section{Classifying Renamo}

In order to assess ONUMOZ' effects on Renamo’s organizational capacities, we should first get a handle on the insurgency's organizational structure. Conflict resolution literature often uses typologies based on the motivations and commitments of various actors. For instance, Stephen Stedman categorizes spoilers in peace processes as limited, greedy, or total, depending on the nature of their demands. ${ }^{6}$

By contrast, I will use a typology drawn from counterinsurgency theory that distinguishes insurgencies primarily with regard to the way in which they mobilize support.

It is easy to romanticize insurgents as expressing the will of a downtrodden populace or demonize them as mere bandits, but both perspectives simplify the political operations of most insurgencies. Every insurgent movement (and every government) has, from time to time, supplemented its genuine popular support with coercive tactics. And every insurgency, no matter how brutal or militaristic, needs some degree of genuine popular support. Nonetheless, insurgencies differ importantly in the relative priority they place on political support and violence, and the role of each. Renamo focused primarily on building its military strength, and seemed to expect support to flow from recognition of that strength. Contrast this with a movement that first builds mass political support and then converts that enthusiasm into a fighting force. The nature of the relationship between violence and popular support in Renamo made it susceptible to techniques of disruption that might not have been effective against a differently-structured movement.

Bard O’Neill divides insurgencies into four strategic types, 'conspiratorial,' ‘urban warfare,' 'protracted popular war,' and 'military-focus."7 Approaches that identify grievances of militant groups with grievances in the population tend to assume that insurgencies are always of the 'protracted popular war' type, where widespread political support for a cause is developed into a capacity for violence. But popular insurgencies are about more than sharing grievances or ideology with a segment of the population. They are built up on a base of popular political organizations, such as parallel government structures (e.g., 'shadow parliaments') or civil society groups like unions or religious organizations. In the earliest phase of a popular insurgency, violence is less important than propaganda and organization. Provision of social services can be important both in gaining support, especially 
if the insurgency is able to fill gaps left by government services, and in building front (or perhaps 'semi-front') groups that provide an organizational base for the insurgents and form the kernel of shadow-government structures. The insurgents may also co-opt existing political structures by recruiting local/community leaders to the cause and integrating their own members into existing community organizations. And, of course, appeals both to ideology and material grievances are important throughout this process. Even as the insurgency progresses, violence is used primarily for political gain and to disrupt the population's relationship to the government - for instance, hit-and-run attacks on government targets are intended to 'isolate the people from the government' by forcing the government into a defensive posture (and, though O’Neill does not note this, the effect is presumably increased if the government is forced to divert resources to the military from constructive projects such as education, health care, etc. - or even from its own ideological/propaganda projects). It is only in the 'end game' that a popular insurgency will attempt to overthrow the remnants of the government.

By contrast, a 'military-focus’ insurgency (hereinafter, a 'military insurgency’), prioritizes military power over political action. Military insurgencies do not engage in deep popular mobilization or organization-building in advance of military operations, either because sufficient organizational structure and popular support is already there (as was the case for the South in the American Civil War) or because they believe that popular support will be forthcoming once their military capacity has been proven.

A military insurgency does ultimately need some degree of popular support to succeed, even though it does not rely as much as a popular insurgency does on having a wellorganized political aspect. Unorganized discontent, even if widespread, will not necessarily topple a government, but generalized discontent or fear can lead people to stonewall that government when its agents come looking for the military insurgents. Moreover, some popular support is needed to supply more troops to the military cause. Support can follow military victory in one of two ways. Where the population has grievances against the government, a small cadre of individuals willing to take up arms may form a nucleus for broader popular uprising. Alternatively, a military insurgency may seek support through fear rather than inspiration; the insurgents' military success can convince the population that only by supporting the insurgents will they be safe. Either inspiration or fear may lead individuals to join (or, in the case of forced recruits, not defect from) an already-organized paramilitary unit, even if they were not previously deeply enough connected to a movement to take up 
arms on its behalf (before it had proven it could win) or if they do not entirely agree with its ideology.

From a peacekeeping standpoint, political mobilization and violence are important because they are the mechanisms through which an insurgency converts passive sympathies into active support. Passive supporters have some sort of inclination toward the insurgency, but are unwilling to provide it material aid. The extent of inclination may not be great insurgencies such as Renamo that rely heavily on fear to maintain control may enjoy passive support only insofar as the population in an area fears the insurgency more than it fears (or respects) the government. Passive supporters are valuable nonetheless, as they are at least unlikely to cooperate with the government against the insurgents, and may engage in other passive resistance. Active supporters participate in the practical operation of the insurgent organization, either as members or through material or political assistance.

While an insurgency needs both passive and active support, active support is more important from the perspective of neutralization. If a large portion of the population is hostile to the government or friendly to an opposition ideology, establishing a stable peace will ultimately require addressing the causes of that discontent. But the discontent itself will not destroy a fragile peace unless some group can effectively mobilize it. Disrupting such mobilization is a more pressing need for peacekeepers than changing overall attitudes.

Active support also poses a more promising target for external intervention. A typical peace operation is neither long enough in duration nor sufficiently integrated with the local population to affect widespread trends in popular opinion. To that extent, the conventional wisdom that 'political will' cannot be manufactured by outside agents is probably true. Fortunately, the problem for external peacekeepers is not to heal all ideological rifts, but only to prevent ideologically-motivated actors from becoming spoilers long enough to achieve a stable environment in which political differences can be resolved peacefully.

Targeting channels of active support is one way of suppressing spoilers. In contrast to passive support, which is primarily attitudinal, widespread, and requires that little from supporters, active support is a matter of overt action, relies on a relatively narrow population base, and requires high-maintenance institutional structures for its operation. The point is rather simple: cutting the line supplying insurgent leaders with active supporters is more feasible for a peacekeeping force than changing the hearts and minds of the much larger population of passive supporters.

This targeting is easier in the case of a military insurgency than a popular one. Popular insurgencies rely on groups whose role extends beyond political violence: political 
parties, farmers' cooperatives, unions, youth groups, etc. A peacekeeping force attempting to disrupt such groups will face difficulties tied to the fact that the primary purpose of these organizations, from the perspective of participants, is often not military at all - e.g., disrupting peasants' collectives will do damage to their way of life, not just remove mechanisms through with insurgents get their food. A military insurgency's active support structures will often be narrower, and more explicitly military. This makes them more promising targets for direct disruption by a PKO.

While Renamo’s nature and motivations are a matter of some controversy, even more sympathetic portrayals of the movement indicate that it was a military-focus insurgency. The debate over Renamo tends to focus on whether or not Mozambicans were genuinely discontented with the government, an issue tangential to an organizational approach. Classifying an insurgency as a protracted popular war or military-focus movement is not about its politics, but rather about its structure. A popular insurgency could set out to garner popular support through cynical deception, and a military-focus insurgency could genuinely believe it had the interests of the people at heart.

In the view of many detractors, Renamo was not only brutal, but essentially a foreign force made up of spies recruited by the Rhodesians since before Mozambique's independence, members of the old Portuguese counterinsurgency units and secret police, and deserters from Frelimo, all 'welded into a fighting unit by the Rhodesian CIO, ${ }^{8}$ whose purpose was to destabilize Mozambique in the service of outside interests. On the other side are those who argue that Frelimo's authoritarian tactics - such as persecution of Catholics and Muslims, ${ }^{9}$ heavy-handed agricultural reform and villagization policies in rural areas, and the displacement of traditional authorities - made it inevitable that the people of Mozambique would rise against the government, making Renamo a natural expression of popular discontent. $^{10}$

Even writers who emphasize the grievances Renamo was ultimately able to tap generally describe it as beginning as a small military group, rather than building its military arm on a base of popular support. The Rhodesians did not initially favour a full-on insurgency, but rather a commando unit - essentially an extension of their long-standing tactic of inserting 'pseudo-guerrilla' CIO units into Mozambique, but now with the added advantage of cooperation and guidance from some native Mozambicans. ${ }^{11}$ André Matsangaice, Renamo’s first leader and a former independence fighter, favoured a more genuinely Mozambican force, but one still organized along primarily military lines. He did not push his side of the dispute by returning to Mozambique and organizing farmers' 
cooperatives in opposition to government agricultural policy or even negotiating with traditional leaders for their support, which would indicate the germ of a popular insurgency, despite Rhodesian involvement. Instead, he returned, first in December 1976 alone and then in May 1977 accompanied by two other defectors, to raid the Sacudzo 're-education' camp and free its prisoners. The first attempt was a notable failure, but the second succeeded. Twenty-eight of the fifty prisoners freed returned to Rhodesia for training, and by July 1977, Renamo numbered two platoons. ${ }^{12}$

Later Renamo strategy followed more or less the same pattern, focusing on infrastructure sabotage and destruction of economically important targets, in keeping with its patrons' goal of destabilization rather than conquest. Attacks on population centres most often had a 'smash and grab' aspect, where officials were killed, citizens conscripted, and loot taken, rather than an attempt to take, hold, and administer territory. ${ }^{13}$ While a terror campaign is 'political' in an extended sense, this is not the sort of movement-building exercise that a popular insurgency engages in to build its capacity to ultimately defeat the government militarily. Renamo may have benefited from passive support born from dissatisfaction with Frelimo, but it did not rely on that discontent to organize its active support.

Renamo’s recruitment, ideological, and population control techniques bear out a military classification.

\section{Recruitment}

Renamo relied almost exclusively on coerced recruitment. Of 32 ex-Renamo members interviewed by William Minter in 1988 (some in a government amnesty program and some captured combatants), 27 indicated that they had been abducted into Renamo. ${ }^{14}$ Minter takes into account the motives that captured or amnestied combatants might have for minimizing their responsibility, but concludes that the level of detail in their stories, as well as Renamo loyalists' willingness to concede that most of their comrades in arms had been forcibly recruited, make their accounts credible. Robert Gersony’s series of 196 interviews for the U.S. State Department, also in 1988, support the view that forced recruitment was Renamo's principal means of filling its ranks. ${ }^{15}$

Even among non-coerced recruits to Renamo, the pattern is more consistent with a military insurgency than a popular one. Non-coerced recruits interviewed by Minter joined Renamo either through specialized contacts (such as the conservative Australian missionary 
who found the movement through an evangelical group) or were recruited by South African military intelligence. ${ }^{16}$

\section{Ideology}

Some writers claim that Renamo had no ideological platform and was purely destructive/rejectionist. ${ }^{17}$ This is an exaggeration, even regarding the movement's early days. Perhaps as early as $1979,{ }^{18}$ Renamo published a platform calling for multiparty democracy and free enterprise, and the Voz da Africa Libre, the Rhodesian radio station associated with Renamo, had expressed such sentiments earlier.

But politics were distinctly secondary to the military program. In 1979, Mastangaice explained that Renamo's political leadership must not exert control over the military elements, and made plans to 'import' external political figures to the movement. ${ }^{19}$ It was only after the 1980 transfer to South African support that Renamo began to cultivate a higher-profile international political persona, rather than acting as a clandestine guerrilla movement. The external, political wing of the movement was always relatively underdeveloped, and seemed to contain few individuals with any meaningful connection to the Renamo fighters in Mozambique. ${ }^{20}$ The content of Renamo's ideology also seemed to be influenced more by military necessity than by conviction. For instance, the movement suddenly stressed its anticommunism and respect for traditional religion when seeking support from the US. ${ }^{21}$

Renamo did play into and benefit from some political discontent with Frelimo’s policies and perceived neglect of the central provinces, but to the extent that an ideology or politics were important to Renamo, it was a way of supporting military aims. Renamo’s leaders may have sincerely believed in at least some of their stated ideology. But the organization seemed to focus much more heavily on military success than on building a political movement. None of Minter's interviewees 'referred to regular political meetings, discussions or courses, and they were clear that they regarded themselves as part of an army, not a political movement.' Only two mentioned political meetings with the civilian populace. $^{22}$

\section{Population and Membership Control}

Renamo's population control techniques varied significantly from region to region, but nowhere included the well-developed structures of a popular insurgency. Gersony divided 
areas of Renamo influence into three types based on the nature of the control exercised: destruction, tax, and control areas. ${ }^{23}$

'Destruction' areas were not really under Renamo’s control in any meaningful sense; they were zones in which Frelimo control was weak enough that Renamo forces could attack population and infrastructure. Even in 'tax' and 'control' areas, Renamo exhibited a preference for coercive and/or indirect control of the population. Renamo police - a mix of former colonial officials and coerced recruits - would patrol for attempted escapes, which were often treated as capital crimes.

In addition to the threat and use of force, Renamo exercised indirect control through the support of traditional leaders, many of who had been sidelined by Frelimo's modernization policies. ${ }^{24}$ Renamo did not make traditional leaders part of their hierarchy, or even seem to use them to build popular support, but relied on alliances with them to gain safe passage and access to resources. Such authorities consulted 'at grass roots level, ${ }^{25}$ but it is not clear how much integration this really indicated and accounts imply that it was at relatively low levels of the organization. Even descriptions of Renamo control in areas where the insurgency was relatively well-received suggests that organizational integration was not extensive - the 'implicit contract between Renamo and the chiefs who invited Renamo to set up bases on their land was that Renamo would block government interference with their way of life... In return, the chiefs would serve as administrators for Renamo. ${ }^{26}$ In all cases, Renamo seems to have handled itself as a separate entity, with an arms-length relationship to traditional administrative structures.

\section{How Successful was ONUMOZ’ DDR Process? In Praise of 'Pay and Scatter'}

Counterinsurgency theory focuses on insurgent organization with an eye toward using violence to disrupt insurgencies. Some of its lessons can be applied outside the strictly military sphere as well. While many PKOs, especially those in a 'traditional' mould, will not be in a position to use brute force to defeat a potential spoiler, other elements of a complex peace operation can be aimed at organizational disruption.

ONUMOZ' DDR process is an example. The disarmament component was generally considered a failure, ${ }^{27}$ which could have seriously undermined the mission's successes in demobilization and political consolidation. The relative failure to disarm the population is confirmed by Mozambique's high postwar crime rate (not to mention South Africa's early 1990s spike in violent crime, which was partially fuelled by weapons making it across the 
border with Mozambique). This rise in violent crime indicates that ONUMOZ did not do a particularly good job reducing individuals' access to weapons. But the failure of Mozambique to return to civil war indicates that something changed with respect to the ease and/or attractiveness of using those arms for political ends. Accounts of ONUMOZ rarely say much about organizational structure, but the UN intervention did take actions that undermined Renamo’s channels of active support. ONUMOZ did not create the political will to end the war, but it did do things that made it more likely that spreading dissatisfaction on both sides would cause organizations to work constructively with the peace process, and less likely that lingering hostility would be mobilized into violence.

It pays to occasionally compare the process of neutralizing Renamo with the attempts to neutralize Angola's UNITA insurgency, which was similarly structured. One of the differences between the Mozambican and Angolan peace processes was over a matter that may seem somewhat trivial and was controversial at the time - the push to 'scatter' combatants quickly as part of the DDR process. ONUMOZ' military leadership (and much of the donor community) often found itself at cross-purposes with UNOHAC's humanitarian operation. UNOHAC focused on long- and medium-term programs that involved building local capacity for tasks such as reintegration and demining. The PKO leadership and many donors were concerned that this strategy neglected the short-term goal of consolidating peace, and that the peace process required a shot in the arm from more direct, and if need be outsider-led, projects with quicker and more visible payoffs. ${ }^{28}$

In the end, the PKO leadership and donors mostly won out: a little over half of ONUMOZ' total disarmament and reintegration funding was spent on a short-term 'pay and scatter’ program, the Reintegration Support Scheme (RSS), and donors often circumvented UNOHAC, for instance by setting up their own combatant reintegration program to extend RSS. $^{29}$ The RSS concept was simple and standard DDR: send combatants back to their home areas (scatter) and provide them with training and short-term pay to ease their transition back into society. While the RSS program has been criticized since, on grounds that to some extent vindicate UNOHAC's concerns with such a short-term strategy, ${ }^{30}$ it was at least a short-term success. I would like to call attention to one subtle but important element in that success.

A quick comparison of Mozambique’s DDR experience with Angola's shows the importance of 'scattering.' Despite difficulties during both Angola's Bicesse (1991) and Lusaka (1997) peace processes, most combatants ultimately received their payments - and both processes ultimately failed, in large part because the UNITA rebels maintained military capacity. ${ }^{31}$ Payment does not seem to have been Angola's problem; slightly larger or 
somewhat more regular payments to combatants are unlikely to have made a difference and, while ‘deeper’ reintegration (job training, education, etc.) programs were not widely undertaken in Angola, these programs are considered a weakness in almost all DDR processes, even relatively successful ones. ${ }^{32}$

The Angolan scatter process, however, faced serious problems. UN officials interviewed by Human Rights Watch during the Lusaka process reported that UNITA officers were ordering combatants to request specific (UNITA-controlled) resettlement destinations, ${ }^{33}$ a charge echoed by the International Organization for Migration (IOM) report. The IOM also reported that many soldiers, denied the ability to change their destination at the last moment, simply remained in the vicinity of the assembly area. ${ }^{34}$

Scattering solves a different problem than payment. Payment and other reintegration programs are aimed at giving combatants options besides war or banditry. Scattering is, at best, incidental to this goal. Combatants may become bandits or productive members of society regardless of where they are.

In the case of a military insurgency, dispersal of combatants may play a significant role in disrupting the organization's ability to operate. Renamo was a tightly-organized and hierarchical military operation. ${ }^{35}$ And, as noted before, its organizational structures did not permeate the non-military life of the country. As a result, it may have been especially susceptible to disruption through geographic dispersal of its members. A popular insurgency would likely have had an easier time regrouping after demobilization and dispersal, since it would have retained many of the popular institutions built to support the insurgency in the first place. Reconstituting a military capacity would have been a difficult task for Renamo because its members had been taken out of contact with their officers (who could not, therefore, either easily communicate with them or apply coercive measures used to maintain the population of forced recruits), were not bound to the organization by strong ideological ties, and were not involved with affiliated organizations such as peasants’ collectives.

Renamo's own prior control tactics demonstrate the importance of location. Renamo commonly transferred new conscripts to areas of Mozambique far from their homes, and typically created units of mixed geographic origin. ${ }^{36}$ This made it more difficult for recruits to run away, it cut their ties to their original communities, and it encouraged them to build new social relationships centred on Renamo.

Why did Renamo’s leadership allow their troops to be scattered during the demobilization process when other movements, like UNITA, have succeed? Both Renamo and Frelimo attempted to reserve some forces from the demobilization process. ${ }^{37}$ Such plans 
were met with resistance from the rank and file: combatants in the AAs rioted when demobilization was delayed, and Renamo leaders brought in to quell unrest found themselves the targets of violence from their troops. ${ }^{38}$ Renamo troops not sent to the AAs also created 'spontaneous' assembly areas by detaining UN and international aid workers, and demanding demobilization. It is not clear whether these soldiers simply were not informed of the demobilization because of a failure of communications within Renamo, or whether their leaders' plans had been to keep them in reserve. ${ }^{39}$ If the latter, the would-be reserve troops were not interested in remaining in reserve.

Several factors conspired to prevent Renamo’s leadership from forcing its troops to stay put. First, part of Renamo’s strategy had been one of information control. Minter’s interviewees reported that they were told the government's 1988 amnesty program was a lie, and that they would be killed if they revealed themselves - disinformation that was taken seriously because the interviewees had little independent access to outside information or personal radios. ${ }^{40}$ Contact with the UN personnel at the AAs would have significantly eroded this sort of disinformation-based control.

Secondly, coercive control requires either an effective threat of punishment or the withdrawal of some benefit. By 1992, the Renamo leadership’s capacity to credibly threaten either was seriously damaged. Both the government and Renamo were having difficulty paying, equipping, and feeding their soldiers by the time of the accords. ${ }^{41}$ This, combined with the breakdown in communications control, would certainly have hampered the Renamo leadership's ability to threaten their rank and file with effective punishment.

The benefits of Renamo membership also declined with the withdrawal of major South African support in 1990. While Renamo retained some access to informal support by right-wing groups in South Africa, Portugal, and the United States, these groups could not match the level of resources available through an official government backer. Unlike Renamo, UNITA had substantial native economic operations in the form of diamond mines. UNITA earned between US\$2.5 and \$3.2 billion from diamond sales from 1993-1998, or in the neighbourhood of $\$ 400$ to $\$ 500$ million per year. ${ }^{42}$ UNITA was receiving only between $\$ 15$ and $\$ 20$ million per year from the US, at peak support in the late 1980 s. $^{43}$

This economic situation has two implications. First, even after the withdrawal of external funding (most of which was gone by the failed 1992 elections), UNITA membership carried economic benefits - unlike Renamo. The second has to do with the nature of these financial resources. Angola's primary economic resources are oil and diamonds, which require a relatively sophisticated organization both to extract and to sell on the international 
market (and they must be sold to be of use - you cannot eat diamonds, or kill your enemies with them). Mozambique's major resources are agricultural products. ${ }^{44}$ Especially after the 1992 droughts, Renamo would have been able to offer many fewer benefits to its members through the resources it controlled. In addition, while Renamo was controlled in a very hierarchical manner, the resources it had access to could also be extracted directly through banditry (a fact that Mozambique’s high post-conflict crime rate seems to bear out), without requiring access to Renamo’s organizational structure.

ONUMOZ’ success at geographic dispersal combined with Renamo’s resource dynamics and organizational structure to disrupt Renamo’s organizational cohesion during the peace process. On a superficial level, Renamo’s inability to maintain a spoiler force through the DDR process may look like a failure of 'political will' to continue the fight on the part of its leadership or rank-and-file. But deeper analysis shows a more nuanced picture. Renamo soldiers were not just not interested in fighting anymore - the evidence is that many Renamo soldiers were never personally committed to fighting for Renamo's cause. Their organization could no longer as effectively coordinate any willing fighters nor incentivize any less-enthusiastic ones as it once did.

\section{Realigning Renamo}

ONUMOZ not only took active steps to disrupt Renamo’s military control, it also acted to change the insurgency's organizational orientation. Contemporary complex PKOs often include a plan for holding elections, in which various once-violent factions are expected to stand as candidates. Less attention often seems to be paid to how an insurgency is to become a political party. When dealing with protracted popular war insurgencies, this may not be a grave problem, since such insurgencies already have well-developed political structures. Military insurgencies, by contrast, may simply not be designed for politics.

Renamo was a military organization that made some nods towards having a political platform. The mere fact of its existence as an organization did not mean that it could effectively carry out the tasks of a political party:

Drawing up a manifesto requires qualified personnel and this is something Renamo lacked... the movement lacked qualified and experienced personnel in all areas of political, economic, social and health administration, public relations, political negotiations, diplomacy, and of course, the all-important area of political canvassing and campaigning. Nearly all of Renamo's cadres were military men who had known little else but how to wage war. ${ }^{45}$ 
Renamo’s relatively successful transition to a political party was not a mysterious occurrence fundamentally inaccessible to outside influence. It began in 1989, before the involvement of the UN when Renamo convened its first Party Congress in response to moves towards multiparty democracy by Frelimo, and began shifting its internal structure away from a pure military focus. ${ }^{46}$ Two features of the Mozambican peace process also helped change Renamo’s organizational character: the administrative arrangement laid out in the GPA, and the UN trust fund.

Section III.8 of Protocol V of the GPA partly formalized Renamo control of portions of the country. In particular:

'...the Parties agree that the institutions provided for by law for the conduct of the public administration in the areas controlled by Renamo shall employ only citizens resident in those areas, who may be members of Renamo,' and '[t]he Government undertakes to respect and not antagonise the traditional structures and authorities where they are currently de facto exercising such authority, and to allow them to be replaced only in those cases where that is called for by the procedures of local tradition themselves. ${ }^{47}$

Especially given that what genuine support Renamo had in areas under its control tended to come from traditional leaders (see above), these provisions amount to a partial recognition of Renamo's political authority in some sections of the country, allowing Renamo to administer sections of the country in advance of the election campaigns, even during the DDR process. One advantage was that this gave Renamo both the incentive to administer areas well, since this was a more promising tactic for winning the upcoming elections than intimidating the populace directly, ${ }^{48}$ and some experience ${ }^{49}$ in functioning as a political rather than military organization.

At the risk of over-anthropomorphizing, the dual administrative structure gave Renamo 'something to do,' besides focus on trying to maintain its military strength. Despite its leader's protestations that he was not 'another Savimbi' (UNITA's leader), the experience of insurgencies that have shed violent splinters when the main group enters peace negotiations shows that the Renamo leader's own inclination to peace may not have been enough to restrain the organization. Of course, the existence of an alternative mission for the organization may also not have been enough - if, e.g., Renamo was entirely unable to manage its provinces to its benefit, or there were members or factions ideologically committed to violence (or total victory). But the alternate organizational purpose would help 
to channel the efforts of individuals who were interested in an alternative to return to war, while depriving violent dissenters of the organization's core institutional resources.

Transforming a military insurgency into a political party requires more than good intentions and a well-written peace agreement - it requires resources. As much as being a military organization requires weapons, logistics, uniforms, and so forth, being a political party requires media access, ways of assessing public opinion, vehicles to reach constituents, etc.

ONUMOZ, with donor support, set up a \$10 million trust fund to assist in Renamo’s transition to a political party. UN rules for the administration of this fund were rather restrictive - for instance, the funds could not be used to hire political consultants, blocking Renamo from quickly gaining access to some of the expertise it needed. ${ }^{50}$ The SRSG had, however, a rather liberal attitude towards the fund's rules, and was known for not requiring receipts for all expenditures. ${ }^{51}$ This allowed Renamo more flexibility, for instance to reward traditional leaders and thus reinforce its political connections to the peasantry. ${ }^{52}$

While providing a violent insurgency with the resources to transform itself may seem uncomfortably like bribery, Mozambique's experience indicates that it may be helpful, or even necessary.

\section{Lessons for Organizational Disruption}

The extensive use of the qualifier 'may' in the above essay indicates its tentative character. I have tried to draw out some trends and elements that have not been emphasized in the existing analyses of Mozambique’s peace process, and show how organizational insights associated with counterinsurgency can be extended to elements of a peace process. Of course, any generalization of these considerations, even if they are accurate, should be undertaken carefully. Nonetheless, focusing on the organizational structure of insurgencies does have the potential to move at least a few elements from the murky realm of 'political will' into the realm of factors over which international actors may have an influence. At the very least, having more possible 'levers’ available during a peace process, rather than fewer, could be a benefit.

At least three tentative conclusions can be drawn from the preceding analysis: 
- Counterinsurgency is relevant beyond the military phase. The tradition of counterinsurgency thinking is, of course, a valuable resource for peacekeepers taking military action against spoilers. But the end of overt military confrontation is not the end of an intervention force's role in disrupting threats to the peace. The same way that a military offensive might be aimed at isolating an insurgency and cutting its supply lines, political action during a demobilization and peace process can be aimed at isolating a violent faction's leadership from its constituency and blocking the channels through which it mobilizes active support. Military-focus insurgencies will be significantly easier for outsiders to disrupt or isolate than protracted popular war movements.

- Changing the context of weapons is as important as reducing their numbers. In terms of weapons collected, ONUMOZ' disarmament was a failure. It may be more fruitful to focus on democratization and elimination or transformation of potential spoiler groups than on disarmament; a reasonably robust government with the support of most organized groups can deal with criminal violence, even if extensive, more easily than a short-term intervention may be able to.

- Organizations are not always ready to be co-opted. The need to bring various factions into the political process is a commonplace concern. But those orchestrating peace processes should realize that bringing in a potential spoiler group is not just a matter of convincing its leadership to play by the rules. Some groups are not organizationally prepared to function as, e.g., political parties, despite their ideological protestations. Peacekeepers should attend to the specific needs of an organization trying to re-shape itself into a political organization, and consider other possibilities for transformation (such as the successful conversion of the Kosovo Liberation Army into the Kosovo Defence Force).

Acknowledgments: The author would like to thank Nancy Gallagher, Anna Kuznetsova, Melissa Schober, Joshua Smith, and John Steinbrunner for comments on earlier drafts of this piece.

\footnotetext{
${ }^{1}$ Ken Flower, Serving Secretly, London: John Murray, 1987, p. 262.

${ }^{2}$ Dennis C. Jett, Why Peacekeeping Fails, New York: St. Martin’s Press, 1999, p. 119.
} 
${ }^{3}$ Moisés Venâncio, 'Can Peacekeeping be Said to Have Worked in Mozambique?' in Moisés Venâncio and Stephen Chan with Chris Alden and Sam Barnes, War and Peace in Mozambique, New York: St. Martin’s Press, 1998, p. 106.

${ }^{4}$ Martinho Chachiua and Mark Malan ('Anomalies and Acquiescence: The Mozambican Peace Process Revisited', African Security Review, Vol. 7, No. 4, 1998, accessed at www.iss.co.za/pubs/ASR/7No4/Anomalies.html) point out that the people undertook reconciliation measures even before the ceasefire and the arrival of ONUMOZ.

${ }^{5}$ Chachuia and Malan (see n.4 above). Of particular note were soldiers disillusioned with their leadership and demanding immediate demobilization. Chachiua and Malan cite a report to the effect that 'the 317 mutinies which were registered in the assembly areas provided a demonstration of the former combatants' disapproval of the leadership of their former armies, rather than a sign of dissatisfaction with the demobilisation programme'

${ }^{6}$ Stephen J. Stedman, 'Spoiler Problems in Peace Processes', International Security, Vol. 22, No. 2, 1997, pp. 10-11.

${ }^{7}$ The discussion of insurgency types and passive/active support follows Bard E. O’Neill, Insurgency and Terrorism: From Revolution to Apocalypse, $2^{\text {nd }}$ Revised Edition, Dulles: Potomac Books, 2005, pp. 46-63.

${ }^{8}$ William Minter, Apartheid's Contras, New Jersey: Zed Books, 1994, p. 33.

${ }^{9}$ Moisés Venâncio and Stephen Chan, 'War and Gropings Towards Peace’, in Venâncio et al (see n.3 above), p. 7.

${ }^{10}$ See, e.g., Christian Geffray, La Cause des Armes, cited in Minter (see n.8 above), p. 207; Martin Meredith, The Fate of Africa: A History of Fifty Years of Independence, New York: Public Affairs, 2005, p. 609-10.

${ }^{11}$ João M. Cabrita, Mozambique: The Torturous Road to Democracy, New York: Palgrave, 2000, p. 144; Venâncio and Chan (see n.9 above), p.3; Colin Legum, 'The MNR', CSIS Africa Notes, No.16, 1983, p. 1-2.

${ }^{12}$ Cabrita (see n.11 above), p. 145, 147-8.

${ }^{13}$ Minter (see n.8 above), pp. 192-3; Ciment (see n.11 above), pp. 193-4; Legum (see n.11 above), p. 3.

${ }^{14}$ William Minter, 'Inside Renamo As Described by Ex-Participants', Transformation, No. 10, 1989, p. 5.

${ }^{15}$ Robert Gersony, Summary of Mozambican Refugee Accounts of Principally ConflictRelated Experience in Mozambique, Washington, DC: US Department of State, 1988, accessed at pdf.dec.org/pdf_docs/PCAAA945.pdf, p. 19.

${ }^{16}$ Minter (see n.14 above), pp. 4-5.

${ }^{17}$ Hilary Andersson, Mozambique: A War Against the People, New York: St. Martin’s Press, 1992, p. 64; James Ciment, Angola and Mozambique, New York: Facts on File, 1997, pp. 183-4.

${ }^{18}$ This is Cabrita’s (see n.11 above, p. 169) date. Ciment (see n.18 above, p. 184) and Tom Young ('The MNR/Renamo: External and Internal Dynamics', African Affairs, Vol.89, No.357, p. 501) place the 'Manifest and Programme' in 1981 or 1982, but claim that propaganda efforts were lackadaisical even after that.

${ }^{19}$ Cabrita (see n.11 above), pp. 167-170.

${ }^{20}$ Young (see n.19 above), pp. 496, 503.

${ }^{21}$ Ciment (see n.18 above), p. 184; Young (see n.19 above, pp. 501-2) believes Renamo’s 1988 platform document may have been written with the assistance of the conservative USbased Heritage Foundation.

${ }^{22}$ Minter (see n.14 above), pp. 12-13.

${ }^{23}$ Gersony (see n.15 above), pp. 16-33. 
${ }^{24}$ Minter (see n.14 above), p. 15.

${ }^{25}$ Venâncio and Chan (see n.9 above), p. 8.

${ }^{26}$ Minter (see n.8 above), 208.

${ }^{27}$ See, e.g., Ana Leão, Weapons in Mozambique, Pretoria: Institute for Security Studies, 2004, p. 14.

${ }^{28}$ Mats R. Berdal, Disarmament and Demobilisation after Civil Wars, London: Oxford University Press for the International Institute for Strategic Studies, 1996, pp. 41-42.

${ }^{29}$ Venâncio (see n.3 above), pp. 112-113; Jaremy McMullin, 'Reintegration of Combatants: Were the Right Lessons Learned in Mozambique?', International Peacekeeping, Vol.11, No.4, pp. 627ff.

${ }^{30}$ McMullin (see n.30 above), pp. 630ff, generally; Alex Vines, 'The Struggle Continues: Light Weapons Destruction in Mozambique', Basic Papers, No. 25, 1998, accessed at www.basicint.org/pubs/Papers/BP25.htm, on criminal violence; Ciment (see n.18 above, p. $180)$, on NGO proliferation.

${ }^{31}$ João Gomes Porto and Imogen Parsons, Sustaining the Peace in Angola, Pretoria: Institute for Security Studies, 2003, pp. 19-27.

${ }^{32}$ See the discussion in Berdal (see n.29 above), pp. 47-51.

${ }^{33}$ Alex Vines, Angola Unravels, New York: Human Rights Watch, 1999, p. 34.

${ }^{34}$ International Organization for Migration, Report on IOM Angola Demobilization-Related Activities 1997, Geneva: International Organization for Migration, 1998, accessed at dw.angonet.org/pmu/dynamicdata/documents/IOM\%20Angola\%20Final\%20Demob\%20Rep ort\%20V7'\%2098.pdf, p. 25.

${ }^{35}$ Ciment (see n.18 above), p. 112; Minter (see n.14 above), pp. 20ff, Eric Berman, Managing Arms in Peace Processes: Mozambique, Geneva: United Nations Institute for Disarmament Research, 1996, p.54.

${ }^{36}$ Minter (see n.8 above), p. 180.

${ }^{37}$ Chris Alden, 'The United Nations, Elections, and the Resolution of Conflict in Mozambique', in Venâncio et al (see n.3 above), p. 85.

${ }^{38}$ Jett (see n.2 above), pp. 103-4; Alden (see n.38 above), pp. 84-5.

${ }^{39}$ Berman, (see n.36 above), 76-77.

${ }^{40}$ Minter (see n.14 above), p. 10.

${ }^{41}$ See, e.g., Richard Synge, Mozambique: UN Peacekeeping in Action 1992-94, Washington, DC: United States Institute of Peace, 1997, pp. 96-7.

${ }^{42}$ Christian Dietrich, 'UNITA's Diamond Mining and Exporting Capacity', in Jakkie Cilliers and Christian Dietrich (eds.), Angola's War Economy, Pretoria: Institute for Security Studies, 2000, p. 284 and note; see also UN Security Council, Final Report of the Monitoring Mechanism on Angola Sanctions, S/2000/1225, 2000, para. 152.

${ }^{43}$ Federation of American Scientists (FAS), 'União Nacional pela Independência Total de Angola (UNITA)’, FAS, last updated 7 May 2003, accessed at www.fas.org/irp/world/para/unita.htm ${ }^{44}$ Jett (see n.2 above), p. 125.

${ }^{45}$ Moisés Venâncio and Stephen Chan, 'Towards Elections', in Venâncio et al (see n.3 above), p. 55.

${ }^{46}$ Venâncio and Chan (see n.9 above), pp. 23-24.

${ }^{47}$ General Peace Agreement for Mozambique, Rome, 1992, accessed at http://www.usip.org/library/pa/mozambique/mozambique_1991-92_toc.html, Protocol V. ${ }^{48}$ Venâncio and Chan (see n.46 above), p. 57.

${ }^{49}$ One area of particular note is the provision of humanitarian assistance. UNOHAC administered aid through field offices in both Renamo- and Frelimo-controlled areas, but was 
centrally directed and imposed some common standards and operating procedures. Alden (see n.38 above, p. 110) reports that this integration with the UNOHAC bureaucracy was an important factor in the more general reintegration of Renamo administrative structures with Frelimo ones. Renamo may also have learned the political benefits of effectively providing humanitarian aid to 'its' population through its damaging experience with outside aid during the 1992 drought. See Moisés Venâncio and Stephen Chan, 'Roman Talks', in Venâncio et al (see n.3 above), p. 37.

${ }^{50}$ Venâncio and Chan (see n.46 above), p. 57.

${ }^{51}$ Jett (see n.2 above), p. 77.

${ }^{52}$ Venâncio (see n. 3 above), p. 101. 